
cash at science is a mistake

\author{
Politicians who seek economic recovery should look beyond the budget of \\ the National Science Foundation, argues Daniel Sarewitz.
}

S everal weeks before the recent US election, I testified before the House of Representatives' Committee on Science and Technology. The topic of the hearing was the 'science of science policy'. In my allotted five minutes, I explained that science investments should be assessed not just in terms of the amount of money spent, but in terms of their capacity to achieve desired social outcomes, such as improved public health or environmental quality.

When it came to questions from the members of Congress attending the hearing - all two of them - Representative Vern Ehlers (Republican, Michigan) ignored my testimony and explained how things were done. Noting that a Republican-led Congress had doubled the budget of the National Institutes of Health (NIH) between 1998 and 2003, Ehlers said that he hoped a new Republican majority in the House would follow suit and this time double the budget of the National Science Foundation (NSF).

Ehlers, who retires this year, holds a $\mathrm{PhD}$ in physics and has served on the science committee since 1994 . So he as much as anyone in Congress should know what makes good science policy. Apparently, it is merely a mastery of the two-times table. President Barack Obama also backs an NSF doubling.

With the United States mired in debt and deficit, and fiscally conservative Republicans now in charge of the House, many government programmes, including research and development (R\&D), will stagnate or be slashed in the next two years. But I predict that the new Republican majority will ally itself with the president to significantly boost funds for the NSF

Can this be plausible? Haven't the Republicans been at war with science, attacking climate-change research and blocking work on embryonic stem cells? Maybe so, but for nearly a decade, Republican lawmakers have also taken the lead in attempts to double the NSF budget. Former House speaker Newt Gingrich, a fiscal conservative who led the 1994 Republican takeover of Congress, has said that he wants to triple the NSF budget.

Why will money flow to the NSF? When times are hard and the political and economic news is grim, throwing money at basic research makes for feel-good politics that plays well in both parties and the media. It also responds to the appeals of scientific and political elites who are obsessed with the idea that the nation is losing its scientific and technological leadership in a globalizing world. Nor is it expensive. The NSF accounts for only 7\% of non-defence R\&D spending.

Boosting funds for basic research is also safer politics than actually tackling a national problem. When Congress doubled the NIH budget, Republicans and Democrats alike claimed that they were improving health care by supporting science. But witness what happened when Democrats
Discuss this article online at:

go.nature.com/nkjl7|

\section{$\checkmark$ NATURE.COM}

tried to address the failings of the nation's medical system directly by passing health-care reform legislation earlier this year. They provoked a powerful political backlash that contributed to last week's electoral defeats.

Unlike almost any other area of government investment, the public accepts that benefits from basic research are unpredictable and long term. Politicians thus get to fob off accountability on the scientific community, whose only responsibility is to ensure that funding goes to the 'best' science. It's no surprise, then, that in many ways the NIH and NSF are the government's crown jewels, extolled by Republicans and Democrats alike because they give away billions of dollars to scientists efficiently, transparently and with minimal scandal or controversy.

So, doubling the NSF budget makes good politics. But what about good policy? Although few would question the value of a robust basic-science enterprise, we just don't know how marginal increases in basicresearch funding affect a nation's capacity to solve social and economic problems. On the other hand, decades of research on the links between science and innovation in areas ranging from jet engines to medicines show that basic research best contributes to economic and social goals when targeted at areas that can directly benefit from additional fundamental knowledge.

If Congress wanted to allocate scarce new R\&D resources wisely during a protracted period of budgetary austerity, it wouldn't adopt a doubling strategy, but would instead take a more surgical approach to set priorities. It would focus investments where links between science and application are well established, to deliver short- to medium-term benefits. Alternative energy, for example, offers many technological options where basic research can improve performance. And if Congress is going to cut R\&D, it could look towards research areas that, despite huge, long-term investment, have shown weak links to desired social outcomes. Much basic research on cancer and on climate change fall into this category.

I know that such an approach would be fiercely opposed by the leading voices of the scientific community, who will never abandon the long-falsified belief that basic research is most valuable to society as a bottom-up enterprise driven only by inherent scientific interest. Moreover, the political attractiveness of generic basic research funded by agencies such as the NSF could be one of the few things that Republicans and Democrats agree on in the next two years. But we shouldn't fool ourselves into thinking that the most politically expedient way to support science is also the most socially beneficial.
Daniel Sarewitz, co-director of the Consortium for Science, Policy and Outcomes at Arizona State University, is based in Washington DC. e-mail:dsarewitz@gmail.com 